\title{
Effects of natural phenolic compounds from a desert dominant shrub Larrea divaricata Cav. on toxicity and survival in mice
}

\author{
Efectos de los compuestos fenólicos naturales de un arbusto dominante del desierto, \\ Larrea divaricata Cav. sobre la toxicidad y sobrevida en ratones
}

J.M. RÍOS ${ }^{1,2}$, A.M. MANGIONE ${ }^{*}$ \& J.C. GIANELLO ${ }^{3}$

\begin{abstract}
1 Área de Ecología, Departamento de Bioquímica y Ciencias Biológicas, Universidad Nacional de San Luis, Instituto Multidisciplinario de Investigaciones Biológicas (IMIBIO) CONICET, Chacabuco y Pedernera 5700, San Luis, Argentina 2 Grupo de Ecología de Comunidades del Desierto (Ecodes), Instituto IAOIZA-CONICET, Mendoza, Argentina

${ }^{3}$ Área de Química Orgánica, Departamento de Química, Universidad Nacional de San Luis, Chacabuco y Pedernera 5700, San Luis, Argentina

*e-mail for correspondence: amangion@unsl.edu.ar
\end{abstract}

\begin{abstract}
It is known that generalist herbivores may circumvent intoxication by ingesting small quantities from a mixture of plant secondary metabolites. However a single chemical, a highly toxic one or the most abundant in the mixture could cause toxicity. Survivorship and toxicity in Rockland male mice were measured to determine if the toxic effects of the phenolic resin of creosote bush (Larrea divaricata Cav.) is due to its major constituent, the nordihydroguaiaretic acid (NDGA) or to the total concentration of phenolic compounds in this resin. This objective was accomplished by exposing mice to voluntary feeding on resin-treated rat chow and by oral gavaging of mice with the following doses and compounds: Resin-100 $\mathrm{mg}(\mathrm{n}=7)$, NDGA$15 \mathrm{mg}(\mathrm{n}=8)$, and NDGA-100 mg $(\mathrm{n}=10)$ and Control $(\mathrm{n}=6)$. Our hypothesis was that NDGA is responsible for the toxicity of Larrea divaricata's phenolic resin. Voluntary resin intake by mice had a pronounced toxic effect, producing body mass loss and significant reduction of food intake. Mice gavaged with Resin-100 mg, NDGA-100 mg, and NDGA-15 mg showed a significant reduction in survival probability compared to mice under Control conditions. Animals exposed to NDGA-15 mg had a higher survivorship compared to the NDGA-100 mg animals, and equivalent survivorship to the Resin-100 $\mathrm{mg}$ (containing $15 \mathrm{mg}$ of NDGA) animals. No significant differences in detoxification, measured as glucuronic acid conjugates in urine, were detected among gavage treatments. Therefore, given that just $15 \mathrm{mg}$ of NDGA were enough to produce the same effect as the whole resin, we suggest that NDGA is the main constituent of Larrea divaricata's resin responsible for the toxic effect of the phenolic resin of this plant.
\end{abstract}

Key words: Larrea divaricata, phenolic resin, NDGA, survival, mice.

\section{RESUMEN}

Los herbívoros generalistas pueden evitar la intoxicación ingiriendo pequeñas cantidades de una mezcla de metabolitos secundarios de plantas. Sin embargo, un solo compuesto, uno altamente tóxico o el más abundante en la mezcla es el que podría causar la intoxicación. La sobrevida y la toxicidad en ratones Rockland machos fueron evaluadas para determinar si los efectos tóxicos de la resina fenólica de jarilla (Larrea divaricata Cav.) se debe a su compuesto mayoritario, el ácido nordihidroguaiarético (ANDG) o a la concentración total de compuestos fenólicos en esta resina. Este objetivo fue logrado mediante la exposición de ratones a la alimentación voluntaria de alimento para rata tratado con resina y mediante el gavage oral de ratones con las siguientes dosis y compuestos: Resina-100 mg ( $\mathrm{n}=7)$, ANDG-15 mg $(\mathrm{n}=8)$, ANDG-100 mg $(\mathrm{n}=10)$ y Control $(\mathrm{n}=6)$. Nuestra hipótesis fue que los efectos tóxicos de Larrea divaricata son atribuibles al ANDG solamente. La ingesta voluntaria de resina por ratones tuvo un efecto tóxico pronunciado, evidenciado en una pérdida en masa corporal y una reducción significativa de la ingesta de alimento. Ratones expuestos a gavage con Resina-100 mg, ANDG-100 mg y ANDG-15 mg mostraron una reducción significativa de la sobrevida comparada con ratones bajo las condiciones Control. Animales expuestos a ANDG-15 mg tuvieron una mayor sobrevida comparado con animales expuestos a ANDG-100 mg y una sobrevida equivalente a los animales expuestos a Resina-100 mg (que contiene a su vez $15 \mathrm{mg}$ de ANDG). No se detectaron diferencias significativas en la detoxificación medida como conjugados de ácido glucurónico en orina entre los tratamientos de gavage. Dado que $15 \mathrm{mg}$ de ANDG fueron suficientes para producir el mismo efecto que la resina total, sugerimos que el ANDG es el constituyente principal de la resina de Larrea divaricata responsable del efecto tóxico de esta planta.

Palabras clave: Larrea divaricata; resina fenólica, ANDG, sobrevida, ratón. 


\section{INTRODUCTION}

The genus Larrea (Zygophyllaceae) is comprised of five species, commonly known as creosote bush, distributed from the south western deserts in the United States to southern Patagonia in Argentina. It is a dominant bush in desert environments, and is recognized as an important component of plant communities in deserts. However, there are very few animals which actually feed on the leaves of these species (Mabry et al. 1977). Animals that naturally feed on creosote bush are very selective regarding plant water content, plant resin content or whether the plant has been visited or not by other herbivores (Meyer \& Karasov 1989, Ernest 1994, Campos et al. 2006).

Nordihydroguaiaretic acid (NDGA) is the major component of creosote bush phenolic resin comprising 10 to $15 \%$ of total dry mass of leaves and stems (Tyler 1994). Creosote bush resin represents 10 to $25 \%$ of the dry weight of the plant and NDGA represents up to $40 \%$ of resin dry mass. The remaining $60 \%$ is a complex mixture of partially methoxylated flavones (Mabry et al. 1977).

NDGA is a potent antioxidant and a growth inhibitor of numerous cancer types tested in vivo and in vitro (Biswal et al. 2000). Both NDGA and one of its major metabolites, the $o$ quinones, have been shown to cause nephropathy in rats fed a diet containing NDGA at 0.5 and $3 \%$ over a 74 weeks period (Grice et al. 1968, Goodman et al. 1970). The principal pathway of elimination of NDGA in urine is in the form of its glucuronic acid conjugate metabolite (Lambert et al. 2002).

Creosote bush phenolic resin is also known to deter feeding by arthropods and to complex with protein in vitro (Rhoades \& Cates 1976). Among mammals, it has been shown that phenolic resin does not reduce nitrogen and dry matter digestibility in vivo (Meyer \& Karasov 1991) but does reduce feeding intake while affecting animal energy and water balance (Dearing et al. 2000, Mangione et al. 2000, 2004). Moreover, individuals from populations of the rodent Neotoma lepida that include creosote bush in their diet, show a higher tolerance to creosote bush resin than those that do not incorporate creosote bush in their diets (Mangione et al. 2000).
A major concern in plant animal interactions mediated by plant secondary metabolites (PSMs) is whether the effects of PSMs are due to a single compound or a mixture of them. Few studies have demonstrated experimentally that PSMs mixtures can reduce herbivory more effectively than single compounds (e.g. Adams \& Bernays 1978, Castellanos \& Espinosa-García 1997). On the other hand, in some cases the concentration of a single secondary metabolite within a mixture may explain herbivory reduction (Rodman \& Chew 1980, Vrieling et al. 1991) and plant resistance against pathogens (Arrhenius \& Lagenheim 1983).

The hypothesis that NDGA is responsible for the toxicity of creosote bush phenolic resin was tested. Two predictions were made: one, the amount of NDGA present in resin (NDGA$15 \mathrm{mg}$ ) has the same effect as the whole resin dose (Resin-100 mg containing $15 \mathrm{mg}$ of NDGA), and two, a dose of NDGA equal to the maximum resin intake fed orally to mice (NDGA-100 mg) has a more toxic effect than the same dose of whole resin (Resin-100 mg).

\section{MATERIAL AND METHODS}

\section{Animals and experimental diet preparation}

Animal housing: only male Rockland mice were used in this study to reduce confounding effects produced by NDGA and other lignans that have proven to have potential estrogenomimic effects (MacRac \& Towers 1984, Obermeyer et al. 1995). We were also interested in looking at any possible response in a small sized rodent like Rockland mice, for two reasons: one, most studies on this subject have been done in small sized animals; two the most abundant rodents in American xeric habitats are small sized.

Rockland mice were individually housed in cylindrical cages $(20 \times 16 \mathrm{~cm}$ diameter $)$ and allowed to acclimate for at least one week prior to starting the experiments. When not involved in the experiment, mice were fed mouse-rat chow and water ad libitum (Cargill Gepsa feeds \#025835, Grupo Pilar S.A., Córdoba, Argentina; $24 \%$ crude protein, $7 \%$ maximum fiber, $7 \%$ fat, $1.2 \%$ calcium, $0.5 \%$ phosphorus and $8 \%$ of minerals as shown in 
the tag). Mice were kept at an ambient temperature of $24 \pm 2{ }^{\circ} \mathrm{C}$ and a 10: 14 (light: dark) photoperiod. All procedures were authorized by the Animal Housing Council of the Facultad de Química, Bioquímica y Farmacia of Universidad Nacional de San Luis.

Phenolic resin extraction: a mixture of young and mature foliage was clipped with scissors from twigs $<0.3 \mathrm{~cm}$ in diameter from individuals of Larrea divaricata during June 2003 , in the proximity of route $7, \mathrm{~km} 810$, Departamento La Capital, San Luis, Argentina. The foliage was transported to the Universidad Nacional de San Luis in sealed bags and stored at $-25^{\circ} \mathrm{C}$. Phenolic resin was extracted from foliage by soaking the leaves and twigs in ethyl ether $\left(\mathrm{Et}_{2} \mathrm{O}\right)$ for $30 \mathrm{~min}$ (1: 3, wet leaf mass: volume). The solvent was evaporated under reduced pressure at low temperature. The absence of chlorophyll was confirmed by placing the resin-ether solutions under UV light.

Experimental diet: the resin-treated diets $(0$, $0.5,1,1.5,2.5$ and $5 \%$ of resin in the chow) were prepared as follows: a known amount of resin (depending on the desired concentration of resin in the diet) was dissolved in a volume of $96 \%$ aqueous ethanol (EtOH) equal to $25 \%$ of the mass of powder mouse-rat chow used in the treatment. Control diet (0\% resin) was prepared in the same manner without addition of resin. The EtOH facilitated the complete mixture of the resin and the chow. The resinEtOH solution and the chow were thoroughly mixed and then dried in the dark at room temperature for $36 \mathrm{~h}$. Diets were stored in vacuum-sealed plastic bags at $-25^{\circ} \mathrm{C}$.

Extraction of NDGA: the NDGA utilized in this study was isolated in a previous work from L. divaricata leaves and stems collected in San Luis, Argentina, in the following way: five hundred grams of chopped L. divaricata leaves and stems were extracted by maceration with $800 \mathrm{~mL}$ of sodium hydroxide $(\mathrm{NaOH})$ aqueous solution for $30 \mathrm{~min}$ at room temperature. The mixture was filtered and acidified using concentrated hydrochloric acid $(\mathrm{HCl})$ and stored in darkness at room temperature for 72 $h$. The precipitate was recovered by decantation, dissolved in $\mathrm{Et}_{2} \mathrm{O}$ and partitioned twice against an aqueous solution (5\%) of potassium hydroxide $(\mathrm{KOH})$. The aqueous layer was acidified with concentrated $\mathrm{HCl}$ and partitioned against $\mathrm{Et}_{2} \mathrm{O}$ (x 2). The organic solution was dried with sodium sulfate $\left(\mathrm{Na}_{2} \mathrm{SO}_{4}\right)$, filtered and evaporated under vacuum. Crystals of pure NDGA were obtained after repeated crystallization using ethanol $(\mathrm{EtOH})$.

Identification of NDGA: chemical identification was achieved using spectroscopical methods as ${ }^{1} \mathrm{H}$ NMR, ${ }^{13} \mathrm{C}$ NMR (Bruker AC-200) using $\mathrm{CD}_{3} \mathrm{OD}$ as solvent and TMS as reference; and by EIMS (Finnigan-Mat GCQ-Plus-Ion Trap) by comparison with the spectral data recovered from a reference standard sample of NDGA (Sigma Chemical Co.). Melting point was recorded using a hotplate microscope (Leitz). Optical rotations were determined in chloroform solutions $\left(\mathrm{Cl}_{3} \mathrm{CH}\right)$ (Perkin-Elmer 341 Polarimeter).

High Performance Liquid Chromatography (HPLC): to determine the concentration of NDGA present in the resin used in the experiment we used HPLC. MeOH-soluble resin extracts were analyzed for NDGA on Gilson 322, detector UV 170 with diode array by reverse-phase HPLC on a Phenomenex C18 column (4.6 x $250 \mathrm{~mm})$ using water (solvent A) and acetonitrile (solvent B). $\mathrm{H}_{3} \mathrm{PO}_{4}(1 \%$; v/v) was added to both $\mathrm{A}$ and $\mathrm{B}$ to suppress ionization during chromatography. NDGA was separated from other $\mathrm{MeOH}$-soluble resin components using a linear gradient from 40 to $100 \% \mathrm{~B}$ over $30 \mathrm{~min}$ and at flow rate of $1 \mathrm{~mL}$ $\mathrm{min}^{-1}$. Elution of NDGA was monitored spectrophotometrically (2 $285 \mathrm{~nm}$ ). Retention time was $7.6 \mathrm{~min}$. Quantification was accomplished by peak area integration using our isolated NDGA dissolved in $\mathrm{MeOH}$ at different concentrations. Both NDGA and resin $\mathrm{MeOH}$-solutions were filtered before injections (Advantec filters $0.45 \mathrm{~mm}$ ).

\section{Experimental design}

Experiment 1: sub-chronic exposure. Feeding trial for measuring resin tolerance. The objective of this trial was to determine the minimum amount of resin in the diet capable of producing a negative and consistent effect on mice (MRNE), measured as body mass loss, food intake reduction, resin intake and water intake increase in mice, to be used for preparing the different doses for gavage in experiment 2 . 
To address this objective, six male Rockland mice were exposed to increasing levels of resin in the chow (expressed as percentage of food dry mass). The animals were first offered rat chow with $0 \%$ resin and then switched sequentially to $0.5,1,1.5,2.5$ and $5 \%$ of resin in the chow. Mice were exposed to each treatment for a period of four days. During all treatments, fresh food and water were offered ad libitum daily.

Body mass was measured daily and animals were removed from the experiment if they lost $15 \%$ or more of their initial body mass. Water was supplied in small bottles and water intake was measured by weighing the small bottles daily and corrected for spillage and evaporation. Food intake was calculated daily by subtracting the dried orts (uneaten food) from the amount of food offered every day on a dry matter basis. Daily values of resin intake were calculated as the product of the amount of dry matter ingested per day multiplied by the proportion of resin in the diet at that particular level.

Experiment 2: oral-dosing trials. A new group of animals was used in this experiment. The objectives of this experiment were (a) to determine survival probability of mice after oral administration (gavage) of total resin and NDGA at different doses including the MRNE amount, determined in Experiment 1, and (b) to measure urinary excretion of glucuronic acid for each treatment.

Oral-dose preparation: each dose (Resin-100 $\mathrm{mg}$, NDGA-15 mg, and NDGA-100 $\mathrm{mg}$ and Control) was prepared using propylenglycol (PG) (Cicarelli, Argentina) as the vehicle, and dimethyl sulphoxide (DMSO) (Merk, Germany) was used to help PG to dissolve the resin and NDGA. The dose for each treatment and for each animal was prepared as follows: either $100 \mathrm{mg}$ of Resin or NDGA or $15 \mathrm{mg}$ of NDGA were put in a vial and $40 \mu \mathrm{L}$ of DMSO was added and mixed. Then, $260 \mu \mathrm{L}$ of PG was added and mixed again until the compound was dissolved. For each dose, we obtained a final gavaged volume of $300 \mu \mathrm{L}$. For Control doses the same protocol was followed except that no natural compounds were added. All vials containing doses were stored in the dark at $4{ }^{\circ} \mathrm{C}$ for a week until the experiments were done. Neither at the time of preparation nor just before doses were used, did we observe precipitated, flocculated or suspended particles in the solutions.

Gavage administration: for oral-dose administration each mouse were gavaged with Resin-100 mg ( $\mathrm{n}=7)$, NDGA-15 mg $(\mathrm{n}=8)$, NDGA-100 mg $(n=10)$ and Control $(n=6)$.

Urine collection: immediately after gavage, the animals were placed into glass metabolic cages for urine collection during $15 \mathrm{~h}$ without food and water. Urine drained into an iced plastic vial to minimize bacterial growth and evaporation. After the $15 \mathrm{~h}$ they were transferred to their cages and offered water and food ad libitum.

Glucuronic conjugates excretion: urine samples were frozen at $-25{ }^{\circ} \mathrm{C}$ until they were used. Glucuronides were determined following the colorimetric assay described by Blumenkrantz and Asboe-Hensen (1973). Urine samples were analyzed in duplicate. A $0.5 \mathrm{~mL}$ of dilute urine sample (1/50) was pipetted into a culture tube placed in an iced water bath along with $3 \mathrm{~mL}$ of $0.0125 \mathrm{M}$ sodium tetraborate-sulfuric acid solution. The mix was shaken by Vortex and returned to the iced water bath. Tubes were then heated in a water bath at $100{ }^{\circ} \mathrm{C}$ for $10 \mathrm{~min}$. After cooling, $50 \mu \mathrm{L}$ of the reagent 3-phenylphenol (Aldrich Chemical Co., Milwaukee, USA) (0.15 \% 3phenylphenol in $0.5 \% \mathrm{NaOH}$ ) was added to one set of samples (Blumenkrantz \& AsboeHensen 1973). A urine sample (blank) was prepared, but the reagent was replaced by 50 $\mu \mathrm{L}$ of $0.5 \% \mathrm{NaOH}$. A standard curve was made with known concentration of glucuronic acid (BDH, London) between 25 and $250 \mu \mathrm{M}$. Absorbance was measured at $520 \mathrm{~nm}$ in a Beckman DU-640 spectrophotometer. In some case the urine samples were diluted $1 / 100$ to make the concentrated samples fit within the standard curve range.

Survival measurements: Rockland mice were observed twice a day over a $96 \mathrm{~h}$ period after gavage and removed only if they were found dead.

\section{Statistical analyses}

In Experiment 1 body mass, intake rates of dry matter, water and resin intake were analyzed with repeated measures ANOVA (Wilkinson 1997). Comparison of means between treatments for food intake, resin intake, body 
mass loss from initial value, and water intake was performed by using paired t-tests among treatments and control and adjusted by Bonferroni correction (Wilkinson 1997). In Experiment 2, urinary excretion of glucuronic acid was analyzed with one way ANOVA. Survival probability post-gavage was analyzed using Kaplan-Meier survival analysis (Wilkinson 1997 [SYSTAT]); all values given are without Bonferroni correction. In all cases values are expressed as a mean with one standard error $(\mathrm{n}=$ number of Rockland mice). A value of $\mathrm{P} \leq 0.05$ was considered as statistically significant.

\section{RESULTS}

\section{Phenolic resin extraction}

Extraction of $830 \mathrm{~g}$ wet mass of Larrea divaricata yielded $83.6 \mathrm{~g}$ of total resin, which was stored at $-25{ }^{\circ} \mathrm{C}$. Chlorophyll was not detected under UV light.

\section{Structural identification}

NDGA was isolated as yellowish needles after repeated crystallization. The melting point was $175-178{ }^{\circ} \mathrm{C}$ and the optical rotation was $[\alpha]_{D}^{20}-18.54^{\circ}$. The ${ }^{1} \mathrm{H}$ NMR spectra obtained confirm the identity of the compound used in this study. All data were in agreement with the structure of 1,4-bis(3-4-dihydroxiphenyl)-2,3dimethylbutane (NDGA).

\section{Experiment 1}

Tolerance to phenolic resin: the MRNE was $100.7 \pm 9.08 \mathrm{mg}, \mathrm{n}=6$. Both resin and food intake were significantly different among treatments (increasing levels of resin in the food $),\left(\mathrm{F}_{5,20}=97.29, \mathrm{P}<0.001\right.$, and $\mathrm{F}_{5,20}=$ 35.86, $\mathrm{P}<0.001$, respectively). Control animals ate significantly more food than animals at $5 \%$ of resin in the diet $\left(\mathrm{t}_{4}=14.71, \mathrm{P}=0.002\right)$. Regarding resin intake, all treatments were different except when comparisons were made between 1.5 versus $2.5 \%\left(\mathrm{t}_{4}=-3.53, \mathrm{P}=0.36\right)$; 1.5 versus $5 \%\left(\mathrm{t}_{4}=-4.96, \mathrm{P}=0.077\right)$; and 2.5 versus $5 \%$ of resin in the $\operatorname{diet}\left(\mathrm{t}_{4}=-1.25, \mathrm{P}=\right.$ 1.00) (Fig. 1). Animals at $5 \%$ resin lost significantly more mass $(16 \%)$ from the initial value $\left(t_{4}=8.22, P=0.018\right)$ (Fig. 2$)$. Body mass loss followed food intake in a same manner (Fig. 1 and 2). Resin intake had an effect on water intake $\left(\mathrm{F}_{5,20}=8.66, \mathrm{P}<0.001\right)$. At $5 \%$ of resin, water consumption increased $30 \%$ from control but it was not statistically different $\left(\mathrm{t}_{4}=-3.33, \mathrm{P}\right.$ $=0.43)$. However, water intake did follow resin intake starting at $1 \%$ of resin (Fig. 3).

\section{Experiment 2}

Concentration of NDGA in the resin: NDGA comprised $15.6 \%$ of total phenolic resin. Therefore its equivalents in miligrams were used for dosing during experiment 2 .

Detoxification measured as urinary excretion of glucuronic acid: there were no differences among treatments in the excretion of glucuronides in urine by Rockland mice gavaged with Control, resin or NDGA at different doses $\left(\mathrm{F}_{3,18}=0.527, \mathrm{P}=0.67\right)$ (Fig. 4).

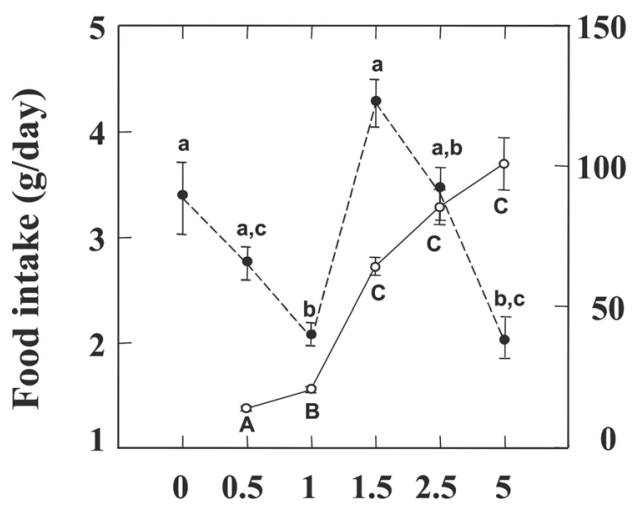

\section{Resin level (\%)}

Fig. 1: Variation in food intake (left y axesdashed line) and resin intake (right y axes-solid line) in Rockland mice in relation to increasing levels of resin in diet. Values are mean \pm 1 standard error. Different small letters represent significant differences in food intake between resin levels (Bonferroni, $\mathrm{P} \leq 0.05$ ). Different capital letters represent significant differences in resin intake between resin levels (Bonferroni, $\mathrm{P} \leq 0.05)$.

Variación en la ingesta de alimento (eje y izquierdo-línea de trazos) y ingesta de resina (eje $y$ derecho-línea continua) en ratones Rockland expuestos a niveles crecientes de resina en la dieta. Los valores se expresan como media \pm 1 error estándar. Diferentes letras minúsculas representan diferencias significativas en la ingesta de alimento entre los niveles de resina (Bonferroni, $\mathrm{P} \leq 0,05$ ). Diferentes letras mayúsculas representan diferencias significativas en la ingesta de resina entre los niveles de resina (Bonferroni, $\mathrm{P} \leq 0,05$ ). 


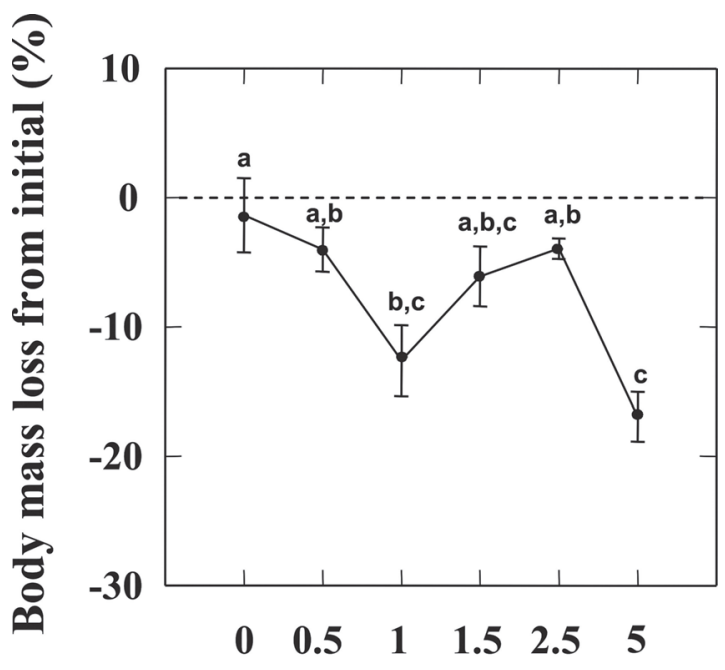

\section{Resin level (\%)}

Fig. 2: Percentage body mass change in Rockland mice in relation to increasing levels of resin in the diet. Values are mean \pm 1 standard error. Different letters represent significant differences in body mass change between resin levels (Bonferroni, $\mathrm{P} \leq 0.05$ ).

Porcentaje de cambio de la masa corporal en ratones Rockland con relación a niveles crecientes de resina en la dieta. Los valores se expresan como media \pm 1 error estándar. Diferentes letras representan diferencias significativas en el cambio de masa corporal entre los niveles de resina (Bonferroni, $\mathrm{P} \leq 0,05$ ).

Survival probability of mice: mice exposed to Resin-100 mg, NDGA-100 mg and NDGA$15 \mathrm{mg}$, showed a significant reduction in survival probability compared to Control $\left(\chi_{3}^{2}=\right.$ 29.1, P < 0.001) (Fig. 5). Survival probability of animals exposed to NDGA-15mg was greater than in animals exposed to NDGA-100 $\mathrm{mg}(\mathrm{P}=0.05)$ (Fig. 5). Even though survival probability of animals with NDGA-100 mg was lower than in those dosed with Resin-100 mg and NDGA-15 mg, these differences were not statistically significant $(\mathrm{P}=0.22, \mathrm{P}=0.49$, respectively).

\section{DISCUSSION}

In this study, a minimum of $15 \mathrm{mg}$ of NDGA was enough to reduce survival down to $50 \%$ at 96 hours after gavage. This result was similar to survival for the Resin-100mg treated animals, suggesting that $15 \mathrm{mg}$ of NDGA has

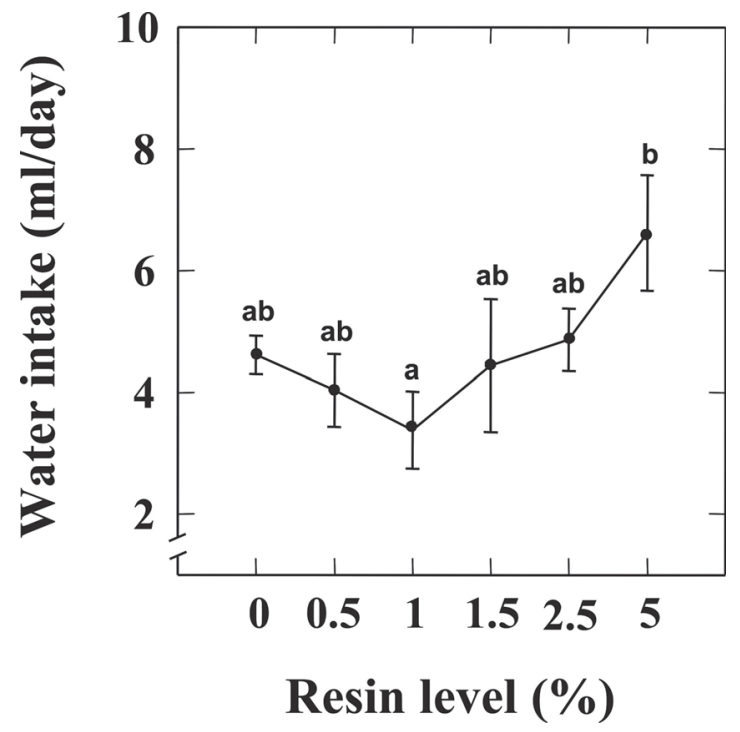

Fig. 3: Water intake in Rockland mice in relation to increasing levels of resin in the diet. Values are mean \pm 1 standard error. Different letters represent significant differences in water intake between resin levels (Bonferroni, $\mathrm{P} \leq 0.05)$

Ingesta de agua en ratones Rockland con relación a niveles creciente de resina en la dieta. Los valores se expresan como media \pm 1 error estándar. Diferentes letras representan diferencias significativas en la ingesta de agua entre los niveles de resina (Bonferroni, $\mathrm{P} \leq 0,05$ ).

the same effect as $100 \mathrm{mg}$ of resin (Fig. 5). In contrast, all animals gavaged with NDGA-100 $\mathrm{mg}$ experienced death at $96 \mathrm{~h}$ and showed severe abdominal inflammation and hair loss. This evidence supports the hypothesis that NDGA alone is responsible for the toxicity of the Larrea's phenolic resin. It is worthwhile to mention that two animals gavaged with $15 \mathrm{mg}$ of resin behaved like Control animals which in the period of post gavage observation did not die or show abdominal inflammation. Rockland mice showed the same responses that have been observed in other species fed orally and voluntarily on Larrea's phenolic resin. For example, they lost weight, increased water intake with increasing levels of resin in the diet, and reduced food intake. This last one is a very common response in which animals drop food intake after being exposed to a toxic compound that they may or may not recognize as harmful, but that may be irritating or stressing. After a short acclimation or 


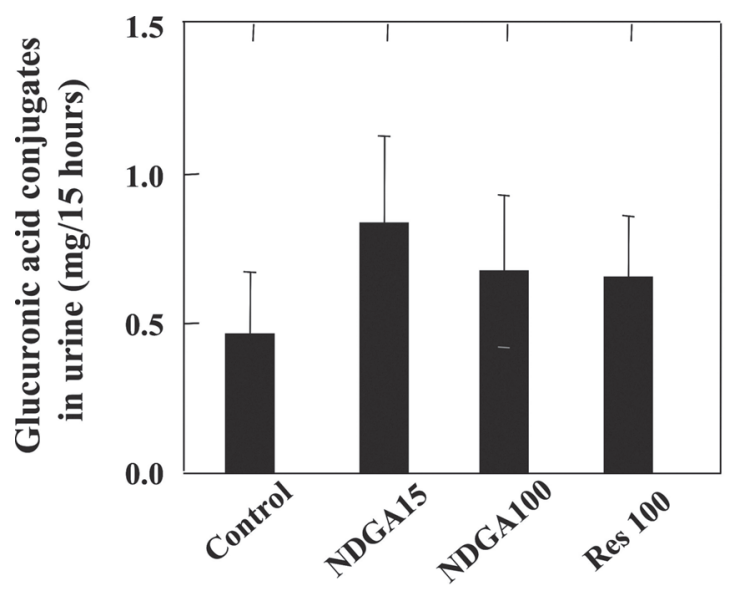

Fig. 4: Excretion of glucuronides in urine of Rockland mice for a 15 -h collection period as a function of gavage dose administration. Each bar represents the mean of glucuronides excreted in urine \pm 1 standard error.

Excreción de compuestos glucuronidados en orina de ratones Rockland en un periodo de colección de 15 h, en función de la dosis administrada mediante gavage. Cada barra representa la media de compuestos glucuronidados excretados en orina \pm 1 error estándar.

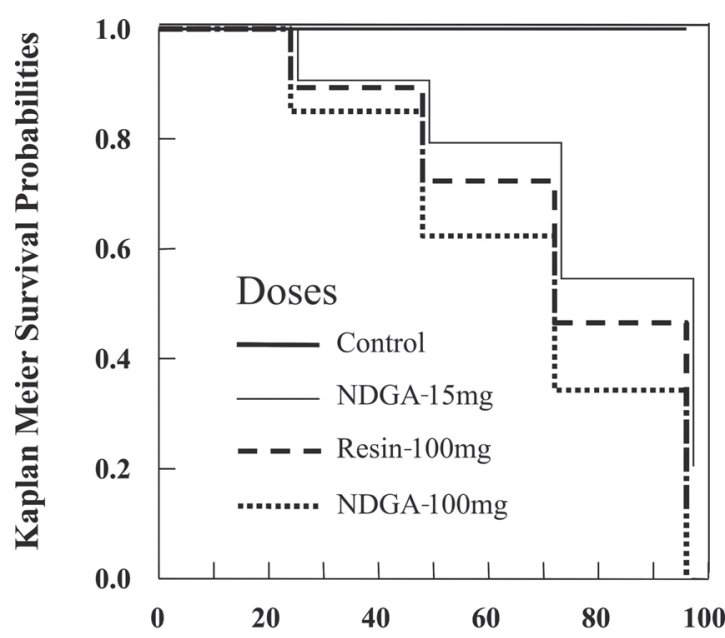

Time (hours)

Fig. 5: Survival probability of Rockland mice after oral dosing trials. Each step indicates that one or more animals had died. The plot depicts the survival function, which captures the probability that animals in one treatment for example, will survive beyond the next time period.

Sobrevida de ratones Rockland luego de la administración oral. Cada escalón indica que uno o más animales han muerto. La gráfica indica la función de sobrevida, que refleja la probabilidad de que los animales en un tratamiento dado, sobrevivan al próximo período de tiempo considerado. habituation period they start eating again (see Fig. 1). There is also a clear correspondence between food intake and body mass loss (see Fig 1 and 2). Altogether, this set of physiological and behavioral responses may be considered as standard effects of the phenolic resin of Larrea spp. on mammals (Mangione et al. 2000, 2001, 2004) and even of other phenolic compounds on birds and mammals (Jakubas et al. 1993a, 1993b, Guglielmo et al. 1996, Bozinovic 1997, Hewitt \& Kirkpatrick 1997).

However, Rockland mice responded differently depending on whether oral ingestion of resin was voluntary throughout the feeding period versus oral gavage of the whole resin or NDGA in a single bolus. Mice tolerated a maximum of $100 \mathrm{mg}$ of phenolic resin in the diet containing $15 \mathrm{mg}$ of NDGA, when feeding voluntarily. In contrast, when animals were gavaged with Resin-100 mg and NDGA-15mg, the doses were lethal (Fig. 5). Sorensen et al. (2005) found that desert woodrats reduce meal size as resin concentration in the diet increases, resulting in a regulation of resin intake. In addition, in a previous study when woodrats were orally gavaged with alpha-pinene, this PSM reached blood concentrations that are potentially lethal to mammals following oral ingestion (Sorensen \& Dearing 2003). The response of Rockland mice in our study is consistent with different meal sizes (doses) and toxin administration/ingestion frequencies. Therefore, the frequency of feeding and dose administration may play a key role on the effects of the toxin. For the purposes of our study however, a single dose of NDGA had the same effect as its phenolic resin equivalent.

Detoxification capacity measured as urinary excretion of glucuronic acid did not differ among treatments (experiment 2, Fig. 4). Several explanations may account for this phenomenon: (a) there may be other detoxification mechanisms used by mammals not analyzed in this study that may play a key role in detoxification of phenols. This finding is surprising; however, glucuronidation is a major capacity, small affinity enzymatic pathway and should help in detoxification greatly (Sipes \& Gandolfi 1991, Mangione et al. 2001). The lack of response of this pathway leads us to think that it is not used by these mice. We think that occurrence of saturation of this detoxification 
pathway is possible; however, we think that given the magnitude of the detoxification process and the fact that there are no differences between control and treatments this is highly improbable. (b) There was not enough time for enzymatic induction for detoxification; however, monoglucuronides of NDGA were found in the blood of Balb/c mice just two minutes after they were dosed with NDGA (Lambert et al. 2002), and desert woodrats showed glucuronides in urine 48 hours after eating $1 \%$ of resin (Mangione et al. 2004). Therefore, we doubt that the lack of enzyme induction time would be responsible for the absence of differences in detoxification among treatments of gavaged Rockland mice; we think that it is possible that the period of 15 hours of collection of urine was not sufficient to collect all the glucuronic acid conjugates produced. (c) Even though glucuronides are not usually eliminated in feces, it is possible that there may have been some that were not measured in this study. We doubt this is the case because only high molecular weight molecules are conjugated and later excreted in feces.

Instead, we propose two explanations for the glucuronic acid results shown in this study. One, before reaching the blood stream, most of the amount of administered NDGA is oxidized to $o$-quinones in the intestine prior to glucuronic acid conjugation. It is proven that, after only $7.5 \mathrm{~h}$, oxidation of NDGA into $o$ quinones reaches a maximum in the ileocaecal junction region of the intestine after a single dose of NDGA administered directly into the rat's small intestine (Grice et al. 1968). So we think that right after oral ingestion of NDGA there might not be substrate for conjugation in the liver.

Two, despite we obtained good solubility of NDGA and the resin for our experiment as evidenced by the lack of suspended particles, flocculated suspension or precipitates of the dose, we cannot rule out that due to changes in $\mathrm{pH}$ in the stomach or in the small intestine, both NDGA and resin may precipitate and therefore be less bioavailable before entering the blood stream.

This study offers a starting point for a more ecological relevant administration of Larrea's phenolic resin and its major constituent, NDGA. Experimental evidence suggests that just $15 \mathrm{mg}$ of NDGA were as lethal as $100 \mathrm{mg}$ of whole resin, suggesting that NDGA is itself the toxic compound in Larrea's phenolic resin.

\section{Ecological implications}

There is a very interesting ecological scenario. Larrea divaricata is extended over more than $30 \%$ of the total area of Argentina (Hunziker et al. 1977), hence there is a high probability that herbivores in general and rodents in particular may be inhabiting a habitat where Larrea spp. are present. However, while in certain habitats creosote bush is one bush among many others available, in other habitats creosote bush may be the only one available. The last systems have already been studied in the Mojave desert in North America, where there are populations of herbivores that incorporate up to $75 \%$ of creosote bush in their diet (Meyer \& Karasov 1989) on sites where creosote bush is almost the only bush available, whereas other populations incorporate only up to $22 \%$ of creosote bush in their diets (Mangione et al. 2000).

We propose that this scenario may be similar for South American rodents. It is then important to know which compound may cause toxicity, but also to know in the near future the physiological capacities to deal with toxic metabolites that would make the difference in food exploitation, distribution, and survival of rodents in extreme environments.

\section{ACKNOWLEDGEMENTS}

We thank Dr. Carlos Tonn for helpful suggestions and comments on this manuscript. Very special thanks to Erik Chapman, Dana Kronental and Nelly Horak for improving the English version of this manuscript. We also thank to two anonymous reviewers for their critical and helpful comments. Professors L. Aragón and E. Saidman provided technical advising on HPLC analyses and Dr. A. Juárez advised on the gavage technique. Animals were provided by Dr. B. Micalizzi. Financial support was provided by Universidad Nacional de San Luis Science and Technology Council to AMM's project 22/Q429 - Plant-animal Interactions: nutritional ecology of vertebrates and to Project 22/Q505 Chemistry and applications of plant natural products. 


\section{LITERATURE CITED}

ADAMS CM \& EA BERNAYS (1978) The effect of combinations of deterrents on the feeding behaviour of Locusta migratoria. Entomologia Experimentalis et Applicata 23: 101-109.

ARRHENIUS SP \& JH LANGENHEIM (1983) Inhibitory effects of Hymenaea and Copaifera leaf resins on the leaf fungus Pestalotia subcuticularis. Biochemical Systematic and Ecology 11: 361-366.

BISWAL SS, K DATTA, SD SHAW, X FENG, JD ROBERTSON \& JP KEHRER (2000) Glutathione oxidation and mitochondrial depolarization as mechanisms of nordihydroguaiaretic acid induced apoptosis in lipoxygenase-deficient FL5.12 cells. Toxicological Sciences 53: 77-83.

BOZINOVIC F (1997) Diet selection in rodents: an experimental test of the effect of dietary fiber and tannins on feeding behavior. Revista Chilena de Historia Natural 70: 67-71.

CAMPOS CM, CE BORGHI, SM GIANNONI \& MF TOGNELLI (2006) Consumo de corteza de jarilla (Larrea cuneifolia) por cuises (Microcavia australis): efecto sobre la supervivencia de ramas y la reproducción. Ecología Austral (Argentina) 16: $1-6$

CASTELLANOS I \& FJ ESPINOSA-GARCÍA (1997) Plant secondary metabolite diversity as a resistance trait against insects: a test with Sitophilus granarius (Coleoptera: Curculionidae) and seed secondary metabolites. Biochemical Systematic and Ecology 25: 591-602.

DEARING MD, AM MANGIONE \& WH KARASOV (2000) Diet breadth of mammalian herbivores: nutrient versus detoxification constraints. Oecologia 123: 397-405.

BLUMENKRANTZ N \& G ASBOE-HENSEN (1973) New method for quantitative determination of uronic acids. Analytical Biochemistry 54: 484-489.

ERNEST KA (1994) Resistance of creosote bush to mammalian herbivory: temporal consistency and browsing-induced changes. Ecology 75: 1684-1692.

GOODMAN T, HC GRICE, GC BECKING \& FA SALEM (1970) A cystic nephropathy induced by nordihydroguaiaretic acid in the rat. Laboratory Investigation 23: 93-107.

GRICE HC, G BECKING \& T GOODMAN (1968) Toxic properties of nordihydroguaiaretic acid. Food and Cosmetics Toxicology 6: 155-161.

GUGLIELMO CG, WH KARASOV \& WJ JAKUBAS (1996) Nutritional costs of a plant secondary metabolite explain selective foraging by ruffed grouse. Ecology 77: 1103-1115.

HEWITT DG \& RL KIRKPATRICK (1997) Ruffed grouse consumption and detoxification of evergreen leaves. Journal Wildlife Management 61: 129-139.

HUNZIKER JH, RA PALACIOS, L POGGIO, CA NARANJO \& TW YANG (1977) Geographic distribution, morphology, hybridization, cytogenetics and evolution. In: Mabry TJ, JH Hunziker \& DR Difeo (eds) Creosote bush, biology and chemistry of Larrea in New World deserts: 115-134. Hutchinson and Ross, Stroudsburg, Pennsylvania, USA.

JAKUBAS WJ, WH KARASOV \& CG GUGLIELMO (1993a) Ruffed grouse tolerance and biotransformation of the plant secondary metabolite coniferyl benzoate. Condor 96: 625-640.

JAKUBAS WJ, WH KARASOV \& CG GUGLIELMO (1993b) Coniferil benzoate in quaking aspen (Populus tremuloides): its effect on energy and nitrogen digestion and retention in ruffed grouse (Bonasa umbellus). Physiological Zoology 66: 580601 .

LAMBERT JD, D ZHAO, RO MEYERS, RK KUESTER, BN TIMMERMANN \& RT DORR (2002) Nordihydroguaiaretic acid: hepatotoxicity and detoxification in the mouse. Toxicon 40: 17011708.

MABRY TJ, DR JR DIFEO, M SAKAKIBARA, CF JR BOHNTEDT \& D SEIGLER (1977) The natural product chemistry of Larrea. In: Mabry TJ, JH Hunziker \& DR Difeo (eds) Creosote bush, biology and chemistry of Larrea in New World deserts: 115-134. Hutchinson and Ross, Stroudsburg, Pennsylvania, USA.

MACRAC WD \& GHN TOWERS (1984) Biological activities of lignans. Phytochemistry 23: 1207 1220 .

MANGIONE AM, DM DEARING \& WH KARASOV (2000) Interpopulation differences in tolerance to creosote bush resin in desert woodrats (Neotoma lepida). Ecology 81: 2067-2076.

MANGIONE AM, DM DEARING \& WH KARASOV (2001) Detoxification in relation to toxin tolerance in desert woodrats eating creosote bush. Journal of Chemical Ecology 27: 2259-2578.

MANGIONE AM, DM DEARING \& WH KARASOV (2004) Creosote bush (Larrea tridentata). Resin increases water demands and reduces energy availability in desert woodrats (Neotoma lepida). Journal of Chemical Ecology 30: 1409-1429.

MEYER MW \& WH KARASOV (1989) Antiherbivory chemistry of Larrea tridentata: effects on woodrats (Neotoma Lepida) feeding and nutrition. Ecology 70: 953-961.

MEYER MW \& WH KARASOV (1991) Chemical aspects in herbivory in arid and semiarid habitats. In: Palo RT \& CT Robbins (eds) Plant defenses against mammalian herbivory: 167-187. CRC Press, Boca Raton, Florida, USA.

OBERMEYER WR, SM MUSSER, JM BETZ, RE CASEY, AE POHLAND \& SW PAGE (1995) Chemical studies of phytoestrogens and related compounds in dietary supplements: flax and chaparral. Proceedings of the Society for Experimental Biology and Medicine 208: 6-12.

RHOADES DF \& RG CATES (1976) Towards a general theory of plant antiherbivory chemistry. Recent Advances in Phytochemistry 10: 168-213.

RODMAN JE \& FS CHEW (1980) Phytochemical correlates of herbivory in a community of native and naturalized Cruciferae. Biochemical Systematic and Ecology 8: 43-50.

SIPES IG \& AJ GANDOLFI (1991) Biotransformation of toxicants. In: Amdur MO, J Doull \& C Klaassen (eds) Casarett and Doull's toxicology: the basic science of poisons: 88-126. Pergamon Press, New York, New York, USA.

SORENSEN JS \& MD DEARING (2003) Elimination of plant toxins by herbivorous woodrats: revisiting an explanation for dietary specialization in mammalian herbivores. Oecologia 134: 88-94

SORENSEN JS, E HEWARD \& MD DEARING (2005) Plant secondary metabolites alter the feeding patterns of a mammalian herbivore (Neotoma lepida). Oecologia 146: 415-422.

TYLER VE (1994) The honest herbal: a sensible guide to the use of herbs and related remedies. Pharmaceutical Products Press, New York, New York, USA. 375 pp. 
VRIELING K, W SMITH, \& E VAN DER MEIJDEN (1991 ) Tritrophic interactions between aphids (Aphisja cobaea Schrank), ant species, Tyriajacobaea L., and Senecio jacobaea L. lead to maintenance of genetic variation in pyrrolizidine alkaloid concentration. Oecologia 86: 177-182.

WILKINSON L (1997) SYSTAT for Windows: statistics. Version 7.0 edition. SYSTAT, Chicago, Illinois, USA.

Associate Editor: Marco Lardies

Received September 20, 2007; accepted January 11, 2008 

